\title{
Muslim Geographies
}

"Muslim Geographies," a conference and public lecture organized by Richard Phillips (University of Liverpool) with support from the Economic \& Social Research Council (ESRC Research Grant RES-000-22-1785), took place on 4-5 April 2008 at Liverpool University and the Merseyside Maritime Museum. The event had several goals: to draw together and advance geographical research involving Muslims, provide a forum for debate about the spaces that shape Muslim lives, and establish informed dialogue between Muslims and non-Muslims as well as between academics and activists. These goals were pursued through a public lecture and debate, to which members of Muslim, activist, and other local communities were invited. To make the conference as inclusive as possible, the event was free, some of the 
sessions were held off-campus, and researchers in architecture, sociology, religious studies, anthropology, public policy, geography, and other disciplines were invited to participate.

The opening session, "Envisaging Geographies of, for, and by Muslims," traced current trends and future directions in geographical research involving Muslims. Peter Hopkins (Newcastle) presented, and the ensuing discussion featured panelists Claire Dwyer (University College London), Ayona Datta (London School of Economics), and Kevin Dunn (New South Wales). The panelists complicated the term Muslim geographies by acknowledging the heterogeneity of Muslims' experiences and identities and expressed concern about how academic research represents Muslims. Nevertheless, they identified the purchase of geographical research on key areas of Muslim life, including their integration, relationships, surveillance, and identities.

Debates about Muslims in Britain and other western countries revolve around claims about their segregation, with many non-Muslim commentators attributing the recent street disturbances and political radicalism to geographical forms of this. In other words, Muslims allegedly choose to live apart. These themes were addressed in sessions on "Integration and Segregation." The debates' broader context was charted by Dwyer, who addressed "Community Cohesion Debates" by discussing faith schooling in Britain, and Sarah Glynn (Edinburgh), who spoke on the interface between Muslims and government in the United Kingdom. Claims and assumptions about segregation were challenged by papers that documented and mapped integration. Kevin Brice (Swansea) spoke on residential integration and Melanie Prideaux (Leeds) analyzed "Muslim-Christian Co-working," while Sarah Hackett (Durham) presented her findings of comparative research on employment patterns among various European immigrant Muslim communities. Philippa Williams (Cambridge) presented on experiences of separation and interaction in North Indian mohalla festivals.

The theme of integration, with non-Muslims living in residential and national communities and with Muslims in other parts of the world, was further explored in "Geographies of Connection," chaired by Tim Bunnell (Singapore). Jamil Iqbal (Leeds Metropolitan University) presented his research on "Local Spaces and Global Mission: Tabligh Jamaat in East London." Two papers were presented on the spaces in and through which Muslims in Spain maintain relationships: Juan F. Carabello-Resto (Aberdeen) discussed the "Reterritorialization of Muslim Identities in Transnational Spaces" through a study of locutorios (Internet and telephone centers, which came under media scrutiny after the Madrid bombings), and Virtudes Téllez- 
Delgado (Madrid) delivered a paper on Internet forums as transnational meeting points for young Muslims from Life Makers of Europe.

Muslim geographies are, all too frequently, spaces of oppression and danger. In a session on "Surveillance and Fear," Rachel Pain (Durham) traced asymmetrical patterns of fear. Most non-Muslims she interviewed in Northeast England were more worried about local youths than "Islamic terrorists." Muslims, however, were found to experience intense anxieties, such as being threatened and constantly watched and suspected. Rachel Finn (Manchester) spoke on the everyday surveillance of South Asian women in New York, while Fatima Khan and Gabe Mythen (Liverpool) examined similar concerns among young British Muslims in Manchester. A session on "Discrimination and Islamophobia" examined experiences of racism in Australia, riots in the northern English town of Oldham, and the difficulties faced by Bengali Muslims in search of housing in London, in presentations by Kevin Dunn (New South Wales), Jamie Halsall (Liverpool), and Datta, respectively.

Several sessions were devoted to "Spaces of Muslim Identities: Sites in Which Muslims Form and Perform Their Religious Identities." These include sacred and other religious spaces. Khalid El-Awaisi (Al-Maktoum Institute, Aberdeen) spoke about the significance and contestation of Islamicjerusalem (Bayt al-Maqdis), and Magda Sibley (Liverpool) reflected upon "Hammams in Islamic Heritage Cities." Kay Chadwick (Liverpool) described the difficulties experienced by French Muslims in establishing mosques, particularly in the suburbs, while Fodil Fadli (Liverpool) charted the establishment of mosques in Northern Ireland. Both explained how mosques are positioned within urban and national contexts, while other speakers examined the changing national spaces that structure Muslim lives. Rhys Dafydd Jones (Aberystwyth) discussed the multi-leveled identities of Somalis in Cardiff, while Sarah Mills (Aberystwyth) showed how Muslim scout groups were instrumental in forging new forms of youth citizenship.

Produced, contested, and negotiated rather than simply inhabited, many of the real and imagined geographies examined in this conference can be empowering for Muslims, whether as a vehicle for identifying and criticizing present Islamophobia or as vehicles for Muslim empowerment. Several papers made this explicit. Fazila Bhimji (Central Lancashire) explained sitespecific expressions of agency by British South Asian Muslim women. Jane Pollard (Newcastle) and Raj Brown (Royal Holloway) identified Muslim economic empowerment through Islamic charitable and banking systems. Reina Lewis (London College of Fashion) showed how Muslim women 
have asserted not only their religious identities, but also their youth and style, through site-specific veiling practices and fashions.

The final open session, "Spaces of Hope for British Muslims," featured three of Britain's leading commentators on contemporary Islam: Tahir Abbas (Birmingham), Ziauddin Sardar (City), and Arun Kundnani (Institute of Race Relations), all of whom were invited to reflect on what Muslims have to be hopeful about today and how others might share this hope. They began by contesting unfavorable assumptions and assertions about Muslims and stressed the difficulties faced by Muslims in Britain and other western countries. However, they found grounds for cautious optimism in some respects: in measured forms of integration, the accommodations and occasional conviviality of multiculturalism, the possibility of resistance, and in the Islamic faith itself. A book based on this conference, edited by Richard Phillips, will be published by Zed in 2009, titled Muslims in the West: Spaces of Hope.

Richard Phillips Reader in Geography, Department of Geography University of Liverpool, United Kingdom 